\title{
The mobile phone, 'modernity' and change in Khartoum, Sudan
}

Inge Brinkman, Mirjam de Bruijn \& Hisham Bilal

\section{Introduction}

This chapter considers the impact and appropriation of the mobile phone in Khartoum, the capital of Sudan, by focusing on the social and cultural processes that accompany it. Central to our argument are local interpretations and meanings attributed to the mobile phone. These new dynamics and debates involve topics as diverse as morality and landscape, family ties and linguistic puns. Through this wide variety of themes we gather not only the hopes and aspirations but also the fears and critique that people in Khartoum may have in connection with the mobile phone.

During its short history, the socio-economic meaning and effect of the mobile phone in Khartoum have undergone vast changes. As the mobile phone was first introduced in Khartoum in 1997, its initial glamour has started to wear off and people are now assessing not only their positive experiences with mobile phones but also the problems related to mobile telephony. People in Khartoum describe the impact of the introduction of the mobile as a combination of benefits and disadvantages, of opportunities and restrictions. Many have come to appreciate the 
possibilities offered by mobile telephony but are wary of the risks and social problems involved.

The focus during the team's fieldwork was, although not exclusively, on university circles and networks related to the educated. Students are known to form an important group of mobile telephone users despite their sometimes limited financial means. And quite a number of university graduates have found employment in the mobile telephone business. For this case-study, some eighteen people working in the sector were interviewed. Except for one, all of them were men. Although a number of women are active in the mobile telephone business, the great majority are male. Interviews were held with people from the highest level in the sector to credit sellers in the market, and they all talked about their activities in the business as well as of their experiences with mobile telephony as end-users. In addition, eight end-users, four of them women, and one non-user were interviewed. The interviews were conducted in various parts of Greater Khartoum.

This chapter is based on research carried out as a pilot study in the framework of collaboration between the telecom company Zain and the African Studies Centre in Leiden that started in July 2007. The study aimed to interpret the interaction between new ICT and social relations, especially with regards to mobility patterns. It consisted of three case-studies: one in Karima, a small town in the north, one focusing on the recent developments in communication technologies in Juba in Southern Sudan and the case-study presented here in Khartoum. The term interaction' was crucial in our focus: we explicitly view ICT not only as shaping societies but also as societies shaping new ICT (de Bruijn \& Brinkman 2008).

Such interaction can only be studied meaningfully with a qualitative methodology. Qualitative research engenders a better understanding of people's evaluations of the mobile phone and the meanings attributed to new communication technologies. The study was inspired by other studies on mobile telephony based on observations in Latin America, the US and Europe. In their approach towards 'communication anthropology', Horst \& Miller (2006) studied the social relations that are created by the use of the mobile phone. Goggin (2006) and Katz (2006) offer an interpretation of aspects of mobile phone culture in which the issue of identity is central. In these approaches, new communication technologies are not seen in deterministic terms: the introduction of the mobile phone does not automatically dictate changes in society. On the contrary, technology and society are defined in a relationship of mutual appropriation. This has also informed our approach and we argue against the thesis of technological determinism that presumes a causal relationship between technology and society. Processes of such mutual appropriation in the past may be instructive, and since such appropriation is likely to be related to particular historical, socio-cultural, economic and political contexts, we 
seek to combine the anthropological qualitative approach with historical interpretation.

The project in Sudan was a pilot study. It was conducted over a five-month period and included a literature study, fieldwork, the transcription of interviews and observations, the writing of a report and the production of a short film. The findings presented here must therefore be regarded as preliminary, and should be read as an invitation to more extensive research into this interesting and important theme.

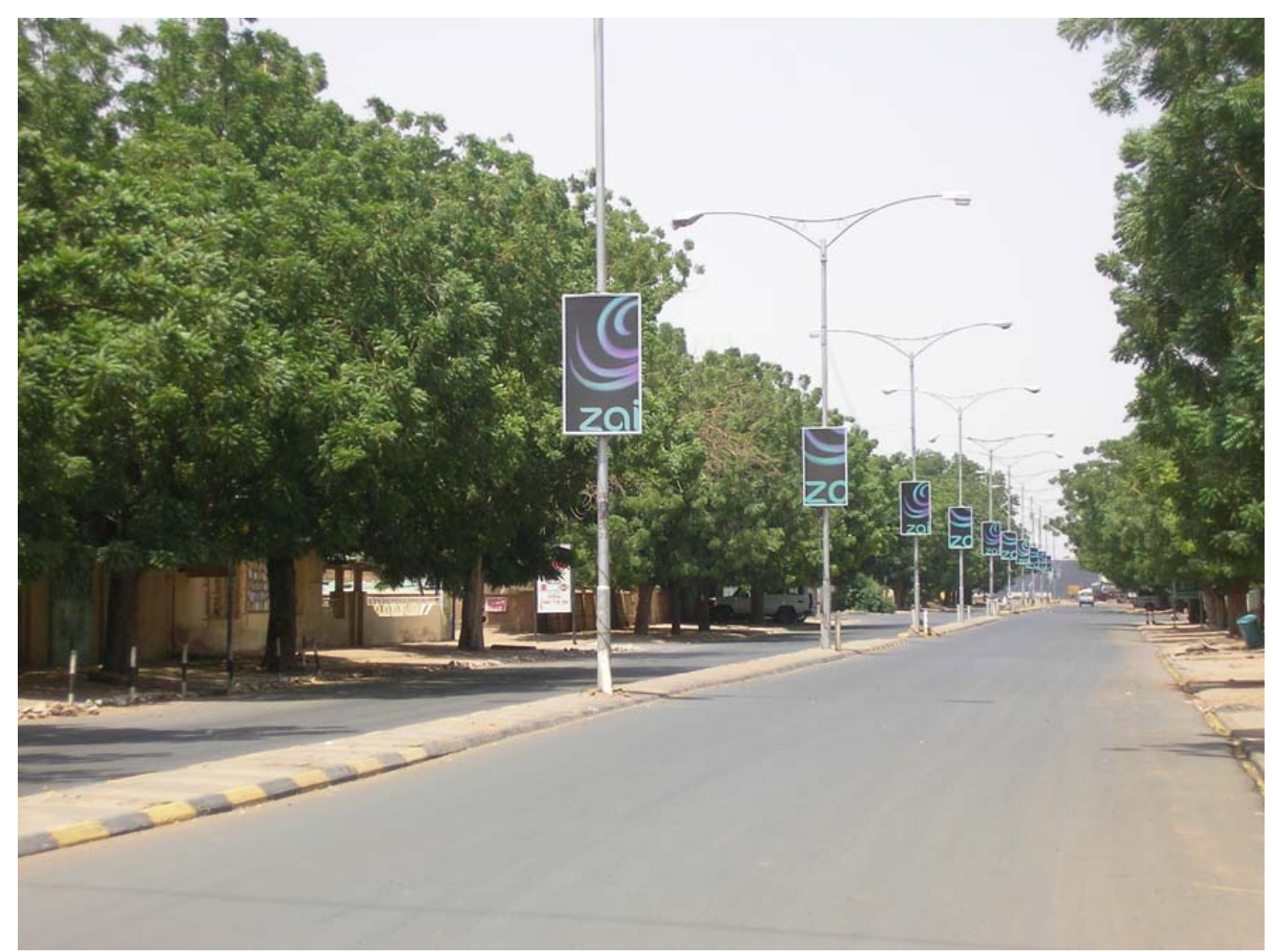

Photo 4.1 Zain Street in Khartoum

\section{Khartoum: The bub}

Although the area where Khartoum is located today had been a settlement for a very long time, the city as such was only established as a small garrison town after Ottoman-Egyptian rule was extended into Sudan in the 1820s. The Ottoman Viceroy of Egypt, Muhammad Ali, saw the expansion into the Sudan as a chance to gain access to local wealth resources based on land, cattle, gold and the slave trade. Situated strategically near the junction of the White Nile and the Blue Nile, the town soon grew, became an important trading centre in the region and was established as the national capital. The Ottoman-Egyptian Empire included many regions of to- 
day's Sudan, although in the south their control was minimal, and their rule was contested in other areas too.

The Mahdist Revolt that started in the 1880s has often been presented as the most successful attempt to resist government by the Ottoman-Egyptians but it was also a movement that focused on religious purity in a politically insecure situation (Holt \& Daly 2000). They managed to take large parts of Sudan, and shifted the capital from Khartoum proper to Omdurman, the town on the opposite bank of the White Nile. For many Sudanese, Omdurman is still the historical capital of Sudan, partly because it is larger and more densely populated. After the Mahdists lost the crucial Battle of Omdurman in 1898, the British returned the capital to Khartoum and General Kitchener planned the city so that its neighbourhoods were in the pattern of the Union Jack (Hamdan 1960). It attracted a growing number of inhabitants and became important as the country's political and administrative centre. A store house and arsenal were built on the other side of the Blue Nile and this area came to be known as Khartoum North (Bahri). It became the major industrial area, although its population also grew over the years from 700,887 at the time of the last population census in 1993 to an estimated 1,725,570 in 2007.

These three towns came to form a conglomerate called Greater Khartoum. Omdurman is by far the largest of the three, having over three million residents. In 1956 the Greater Khartoum area had some 98,000 inhabitants, in 1983 there were well over 1.3 million inhabitants, the total population was approaching 3 million by 1993, and today the figure is over 7 million (Hamdan nd). This growth has been due to natural causes, to international refugees coming from neighbouring countries in the 1970s, and to a large influx of internally displaced persons (IDPs) from the war zones in the south and Darfur from the 1980s onwards.

\section{Khartoum's markets}

Markets are a central feature of this tripartite city. In many cases, markets are linked to transportation facilities and are located near bus stations or large traffic intersections. The important markets include the well-known el Suq el Arabi (Arabian Market) in Khartoum's city centre, Suq Omdurman and Suq Babri, but also the Suq Libya (Libyan Market in Omdurman), the popular el Suq el Shaabi, Suq el Wibda (Unity Market in Khartoum North), Suq el Leffa (Turn Market in Khartoum) and el Suq el Mabali (the Market of the Place). Many people in Khartoum visit one of these markets every day. While road transport is generally sparse in Sudan as a whole, Khartoum's city centre is plagued by long traffic jams and high levels of air pollution as a result. Public transport comes in the form of shared taxis, buses and, within neighbourhoods, rickshaws.

Markets are usually organized by product, with each street offering its own product. Obviously such connections between location and product are subject to 
change. For example, a street in Foreigners' Market in the centre of Khartoum where clothes used to be sold later changed to being a 'mobile telephone street'. ${ }^{1}$ However, in less extensive markets, people have to diversify as much as they can. Thus a businessman may have a licence for a photo shop but at the same time offer credit transfers and repair services in mobile telephony. ${ }^{2}$

The relatively new business of mobile telephony is highly visible in the markets: mobile telephones and accessories are on display and businesses have elaborately decorated shop windows. Street vendors, however, may have no more than a suitcase, three mobile phones (so as to include the Zain, Sudani and MTN networks) and a placard announcing their activities. Survival is precarious for such street vendors: the police may appear at any time, confiscate their wares and demand payment before their possessions are returned to them. ${ }^{3}$

Many of the businessmen are part of extensive international trading networks. One man the research team met had received his education in business and technology in Egypt and now, as a trader, regularly travelled to Dubai to buy products to

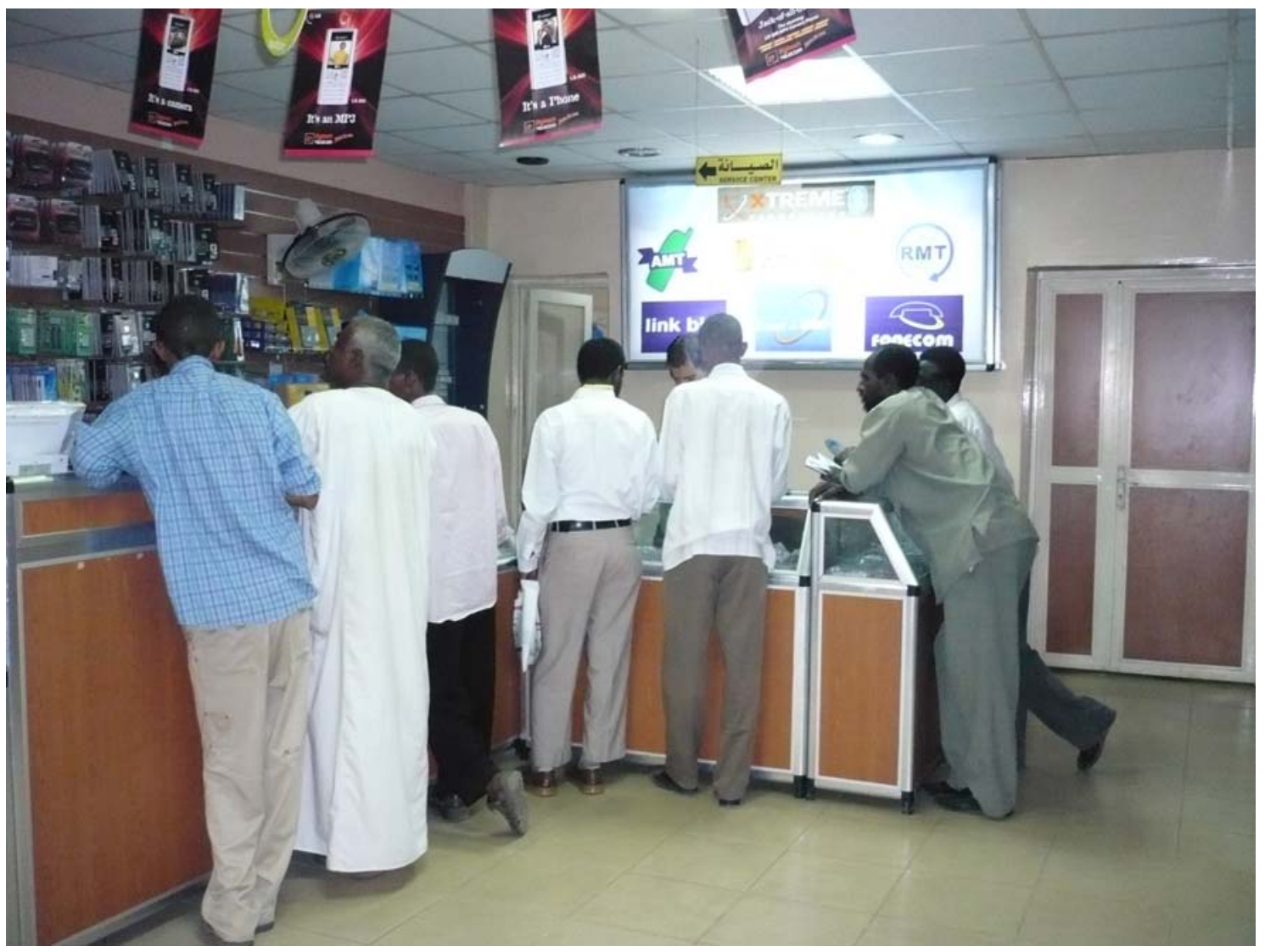

Photo 4.2 A luxury mobile phone shop in Khartoum

Interview with a shopkeeper in Khartoum's Foreigners' Market, 22/09/07 \& 23/09/07.

Interview with a shop owner (photography/mobile phones), Omdurman, 19/08/07.

Interview with a mobile phone shop owner in Khartoum's Arabian Market, 10/08/07. 
sell in Sudan. ${ }^{4}$ The economic chains involved are extensive and, at the multinational level, incredible sums of money are being earned. Some of this is being reinvested in modern, upmarket shops.

The sector also consists of chains of distribution from local shops to market stalls and, like the multinational companies, these are often tied to economic trading networks in Egypt, Saudi Arabia, Dubai, Uganda and elsewhere.

\section{Morality and socio-economic meanings}

\section{Economic opportunities and restrictions}

The mobile phone is opening up a wide range of new economic possibilities for many people. Handsets have their seasons and prices rise sharply round special occasions such as Ramadan and Eid al-Fitr, and during the Hajj pilgrimage period. At this time people import brand new models from the countries they visit and these new phones can fetch up to double the price originally paid for them. It is a risky business, however, as prices can also drop spectacularly soon afterwards.

Economic possibilities are also growing for some merchants not directly involved in mobile telephony. Through their mobile phones, traders can attract new customers and people active in petty trading and small businesses have their mobile phone numbers clearly displayed so that they can be reached by prospective clients.

The advantages of having a mobile phone are especially relevant for women in business. As they are not always allowed to walk outside on the streets and may not be able to travel at all times of the day, making appointments by phone can help them to plan their lives and allow them to operate within the imposed limits of 'respectable' behaviour. The mobile phone can also help to limit the number of fruitless visits they make. For Fatima, a henna painter, the mobile phone constitutes an important income-generating tool. All her customers reach her by phone and she used the first income she ever had (in 2002) to invest in a mobile phone. When asked the reason, she answered: 'I heard that the mobile phone would bring work and that was exactly what has happened.' ${ }^{5}$ Many business people testify that the mobile phone offers new possibilities to fix up business appointments, arrange for wares to be delivered and develop clear time schedules. In short, business organization is greatly enhanced by the mobile phone.

Economics is not only important for those in business. End-users also try to use the mobile phone for their own benefit and as economically as possible. Credit transfer has become an important way of sending money between relatives and between lovers. End-users agree on a 'sign language' so they can place orders with petty traders. Tea sellers, for example, may be reached through a 'missed call' system

\footnotetext{
Interview as above.

Interview with a female henna painter at her house in Khartoum North, 23/09/07.
} 
that costs nothing at all. ${ }^{6}$ The initial purchase of a mobile phone is a financial burden for many people so, to deal with this, students at one of the colleges in Khartoum established a credit association through which they saved money to buy a mobile phone for each member in turn. ${ }^{7}$

Many people have more than one SIM card and, if they can afford it, several handsets. In Khartoum this is predominantly to ensure the best rate: calling contacts with the same operator is usually cheaper and some companies have special rates at night or offer other incentives or promotional packages. Other people use different phones for different aspects of their lives and have separate phones for work and private use. These strategies indicate the lengths people go to in order to reduce costs and gain maximum benefit from their mobile phone.

Concerns were regularly raised during the team's interviews about the risks of spending too much on calling. Some people mentioned a local saying: 'Mobile yakul israb' (the mobile phone eats and drinks with you), implying that a large percentage of a household budget can be spent on a mobile phone. ${ }^{8}$ People who, for whatever reason, do not have access to or can only make limited use of a mobile phone are excluded from the economic networks and chains mentioned above. For some, this is a choice; they may be against the mobile phone in principle or feel that they do not need one. Even so, economic considerations play a role in many of these cases. One non-user indicated that he saw no need to have a mobile phone and mentioned a number of disadvantages related to it, but he also held that mobile phones were too expensive: 'In the past I had one but I stopped it due to the high running costs. The normal telephone is cheaper and it does the same thing that a mobile phone does.' This man saw no need to have a mobile phone as he felt his fixed line was serving him well, but there are also large numbers of people in Khartoum who simply cannot afford a mobile phone.

\section{Social bonds and privacy}

The mobile phone is not only relevant for the economic sector in Sudan. Social bonds are perceived as extremely important in Sudanese society and people are using modern communication technologies to forge, re-establish or reinforce these bonds. In many cases, people use the mobile phone exclusively to create and/or maintain social connections. These may involve existing networks of family and friends but also new networks of mobile phone users. This (re)production of social

\footnotetext{
Interview with the Deputy Directory General, NTC, at NTC's office in Khartoum, 1/08/07.

Interview with a male college graduate working at the International Center for Peace Culture in Khartoum, 7/08/07.

8 Informal conversation with a university teacher and interview with a male trader at his shop in Khartoum North, 9//08/07.

9 Interview as above.
} 


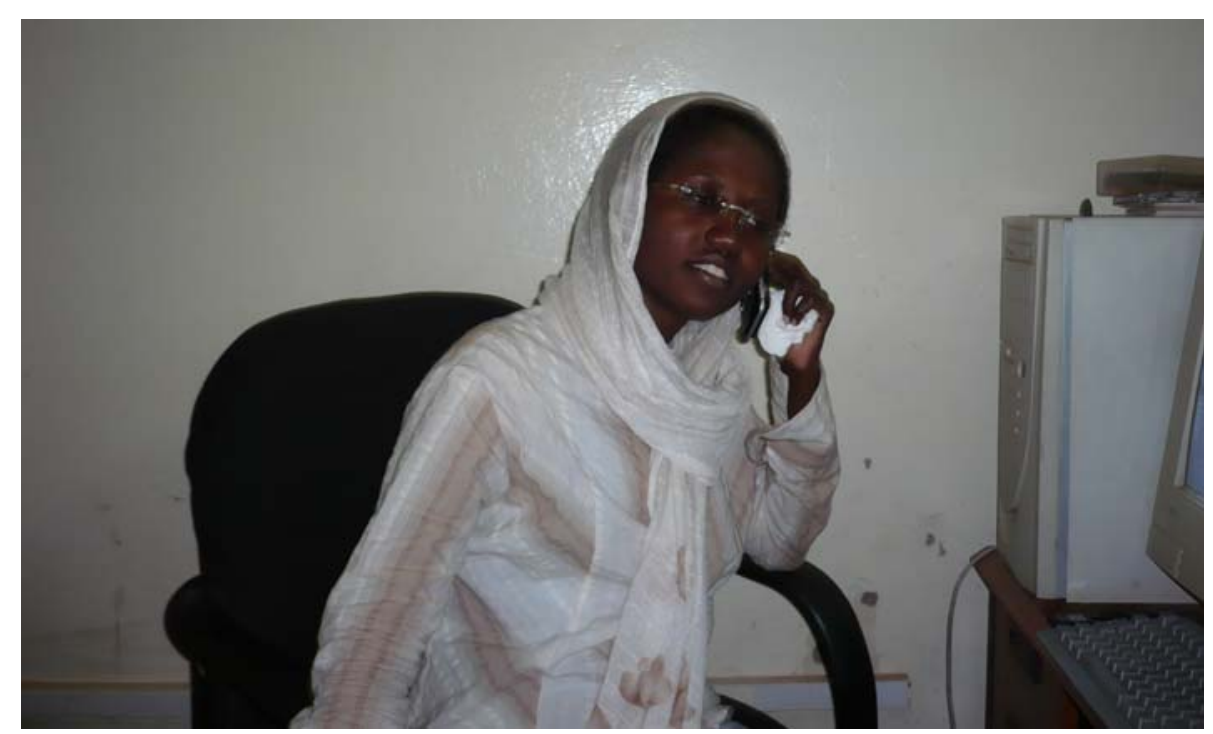

Photo 4.3: 'Credit Hiba'

Hiba is a 26-year-old graduate student at the University of Khartoum who has just begun her practical specialization year at the Ministry of Irrigation. She started university in 2002 and was immediately given a mobile phone by an uncle who lives in the US: 'Uncle Seddig was refusing the idea of a mobile phone but he bought it for me to keep in touch with my family.' As Hiba is from Kordofan and has many relatives in Babrain and the US, it is difficult for her to reach her relatives other than by mobile phone. Soon her bills reached 25,000 Sudanese pounds every quarter, and, although her family helped her to settle the bills, she felt the financial burden had become too high.

That is why she started a credit service a year ago: I thought: if I use the mobile phone to transfer credit on a commercial basis, I can use the money to run my own mobile phone. I use the profit from the credit calls to communicate with my family (my mother, my father and so on). Instead of being a financial burden, my mobile phone covers itself financially.'

Initially she had only a few customers but as her network started to grow her income increased and she no longer spends extra money on her telephone bill. Hib a knows her customers well; most of them are relatives or female friends from university. She experienced problems with some of them as they did not pay her and would try to postpone clearing their financial debt with her indefinitely. That is why she no longer accepts customers who want to pay later. Despite the income she gets from the credit transfer, she stated that she will stop the business as soon as she has a job. Hiba's nickname is 'Hiba Rasiid': 'Credit Hiba'.

For this young woman, the mobile phone constitutes an important way of keeping in touch with her family: 'The mobile phone is one of the technologies which is very effective and we benefit from it. For example, you can use it to communicate with those you cannot reach physically, especially in emergencies, wherever they are.' Once Hiba had to sit an exam but was mistaken about the time. The teacher called her on her mobile phone and, as she was able to appear within ten minutes, allowed her to participate. This way she did not miss her exam, which would have cost her an extra year of study: 'Think about it, if I had not had a mobile phone, how would he have been able to find me?'

Yet Hiba is sharply aware of the negatives side of the mobile phone and feels that it should be used 'rationally', not in a 'bad' way such as for 'immoral relations' in which people 'spend their time chatting on the mobile phone all night'. There are many advantages. It is a means of communication and people use it in their businesses. It can belp people to win millions but at the same time, through it, they can also lose millions in meaningless conversations against God's will!' 
bonds redirects the function of mobile telephony. While designed for communication and information exchange, people in Sudan are also using it as a form of technology to maintain, create and/or expand their networks per se. This explains why some interviewees talked about the 'wrong way' of using the mobile phone.

Sudanese people like to talk very much! That is Sudanese. In Europe it is: 'Hello ... goodbye'. Only a small subject is discussed and then: 'Bye bye'. In Sudan, however: 'How is your family? How is your brother? How are your friends? How are you since the last time I saw you? and so on. Talking very much! That is Sudanese. ${ }^{10}$

In terms of privacy, opinions about the mobile phone vary. Some people appreciate the possibility of talking in private on their mobile phone; in stark contrast to fixed lines in houses and shops. Amr, a young university graduate who deals in credit transfer, explained that privacy was the most important reason for him to buy a mobile phone: 'I think the most important motivation for me to buy a mobile phone is the privacy; that you can be sure that any phone call for you comes to you directly.' 11 Others, however, find it tiring and annoying that they can be reached day and night by everyone and they consider it a breach of their privacy. People can switch off their mobile phone if they feel tired or depressed, or if they can no longer tolerate the indirect form of contact that the phone establishes. ${ }^{12}$ Some people indicated that they cannot survive without their mobile phone and feel anxious without it: 'It is like a drug. After one month you cannot do without it,' one man commented. Obviously such cases of 'mobile phone addiction' are adversely related to the issue of over-expenditure. ${ }^{13}$

\section{Generations and the family}

For many Sudanese, relations within the family are the most intimate and intense ties in terms of social contact. Such ties are not restricted to the nuclear family but may include ever-widening circles of relatives. A number of Sudanese of working age, especially men, have moved away from home to earn an income and this migration may involve moving from the rural areas to a regional town, further afield from one region to another or to Khartoum. International migration, especially to the Arab world - Saudi Arabia, Egypt and other countries - is also common. Many families from war zones have been separated: some members have continued living in the South or Darfur, others have fled as IDPs to Khartoum, and yet others may have ended up in Uganda, Chad or elsewhere. For these families, the mobile phone provides a welcome opportunity to restore or maintain kinship bonds.

10 Interview with a shop owner in Khartoum city centre, 21/07/07.

11 Interview with a male student and credit transferer, Omdurman, 17/08/07.

12 Interview with a male college graduate working at the International Center for Peace Culture in Khartoum, 7/08/07. Interview with a male end-user and journalist at his sister's house in Khartoum, 28/08/07.

13 Interview with the male manager of Mobitel's Arkaweet shop in Khartoum, 30/07/07. 
Family news can be passed on much more rapidly than before. If there is conflict or a problem in the family, decisions can also include absent family members if required, whereas in the past it was usually impossible to reach all the family members who might need to be involved in a discussion. In cases of bereavement, for example, it was often difficult to reach relatives to pass on the news. The mobile phone now offers almost instant access to all family members. ${ }^{14}$

A handset and SIM card have become important presents and remittances that children offer their parents when they work elsewhere. The elderly in most cases do not buy telephones themselves and it is usually those who have an income who buy mobiles both for themselves and for family members. Sons in particular tend to send their parents a mobile telephone so that they can remain in close contact. For many elderly people, their telephone is their 'life line' to the outside world. A 63year-old woman from Sinja who had moved to Khartoum explained in an interview that at first she felt that people with mobile telephones were 'acting crazy'. She regarded the loud and intrusive presence of the mobile phone negatively and was 'shy' about becoming a mobile phone user herself. Now however, she is convinced of the advantages of the mobile phone as it is the only way her sons, who are living abroad, can contact her.

Once when I had been in Sinja my sons were trying to call me and they didn't find me at home. Then they tried at my father's house and they told them that I had gone to my sister's place but when they called me there, I had left already. When I heard that, I decided to get a mobile phone to make it easier for them to find me wherever I am. ${ }^{15}$

The mobile phone intensifies links between the town and the countryside as people working in urban areas can call their relatives and friends 'at home' in the rural areas more frequently.

It is also argued that the mobile phone allows people to lie more easily. When asked what changes the mobile phone had brought to Sudanese culture, a businessman argued:

It changed matters, it really did: everything is different. Before the mobile phone, Sudanese people they would not talk so much but all they said was true, but when this mobile phone came, everybody is just telling falsities on the cell phone. They will always say matters like:

'Where are you?' 'Just near you!' But he is not near me at all, he is maybe two hours away from me! ${ }^{16}$

Many people take a highly balanced view of the relationship between the mobile phone and social interaction:

14 Informal conversation with a university graduate.

15 Interview with an elderly female housewife and end-user at her house in Khartoum, 22/0807.

16 Interview with a male shop owner in Khartoum city centre, 21/07/07; iinterview with a male worker at a credit transfer shop in Khartoum North, 9/08/07; iinterview with a male mobile phone shop owner in Khartoum's Arabian Market, 10/08/07. 


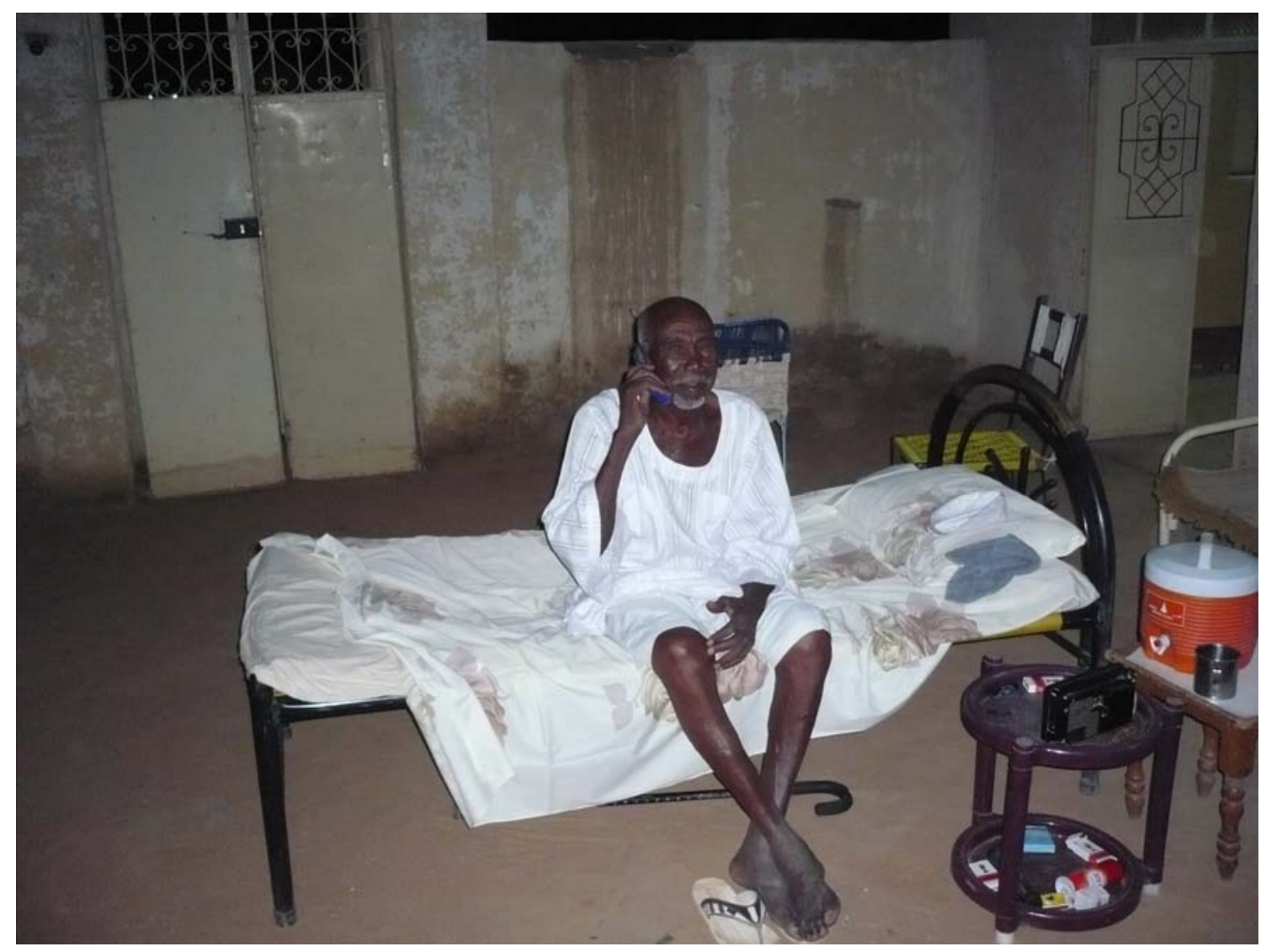

Photo 4.4 Grandfather in the village calling his son in Khartoum

The mobile phone decreases visits between people and this is a disadvantage. Face-to-face interaction between people is more comfortable and people feel free to take their time with this. The mobile phone does not offer this possibility. At the same time, however, it has intensified my relationship with relatives abroad and connects Sudan and its various parts. ${ }^{17}$

Even within the household, informants argue, the mobile phone can lead to increasing distance between family members. Sons and daughters may quickly switch off their mobile phone when parents appear and they then wonder what their children are hiding from them. ${ }^{18}$ Secret conversations tend to be held in their bedrooms where parental control is less. In most cases, these 'secrets' concern relations between the sexes.

\section{Gender and morality}

In line with stereotypical representations of gender relations in Islamic societies, it is often assumed that Islamic women are subordinated and confined to the private sphere, while men dominate the public space and are in charge of the political and economic arena. The reality is infinitely more complex (Nageeb 2004: 1-2). Under

17 Interview with a male electronics engineer in a maintenance shop in Khartoum North, 9/08/07; interview with a male student and credit transferer, Omdurman, 17/08/07.

18 Informal conversation with a university teacher. 
Islamic law, women in Khartoum are subjected to several dress restrictions and, at least in the public space, the sexes have to be kept separate as far as possible. In Khartoum, there is sharp controversy about the nature of respectful Islamic behaviour. In the view of those defending Islamist policies, traditions kept women submissive, while islamization allows women to actively participate in public life. The women interviewed by Salma Nageeb, however, were negative about 'the attacks that claimed traditional norms of gender segregation were not Islamic enough'. They felt that in the past men and women each had their social space and respected each other's activities. In their view, the new Islamist policies have led to a disintegration of this system and, albeit under a veneer of Islamic appearance, disrespectful behaviour.

I see them from my house when they come out of university. They wear their black cloth [referring to the Islamic dress] and cover their heads, but their laughter breaks the ears - walking with men and eating in the street. Where is modesty? (Ibid.: 21-24)

Similar debates about gender relations and morality have also surrounded the introduction of the mobile phone. During fieldwork, it was the issue that was most frequently brought up when discussing the advantages and disadvantages of mobile phone behaviour. Issues of respectful behaviour and sexual morals have become closely tied to the introduction of the mobile phone. Some people hold that the mobile phone directly contributes to immorality and the increasing divorce rate. Appointments can now even be made from the house and keeping a wife confined to her home is no longer enough to 'control' her activities. ${ }^{19}$

Especially for young people, the mobile phone has become a central strategic device in courtship. In the new dynamics of relations between men and women, 'love' is a central theme. Given the financial aspects involved, it is astonishing how many youngsters of high-school age and especially university students have a mobile phone. They regard it as a necessary tool for social networking and will do everything possible to become a subscriber.

Parents may give their daughters a mobile phone in order to be able to exert closer control over their whereabouts but young women overcome these restrictions and use their mobile phones to reach and be reached by admirers. The mobile phone gives, especially women, new opportunities to establish contacts and be masters of their own networking. As one young man explained: 'Communication technology has made it easier to be in touch with a girl. In the past it was difficult because of our traditional society but today they can't control it if a girl has a mobile phone.' 20

Obviously this comes with risks involved. Stories circulate of young women being contacted by mobile phone and lured on a date only to be robbed of their

\footnotetext{
19 Informal conversation with a university teacher.

20 Interview with a male worker at a credit transfer shop in Khartoum North, 9/08/07.
} 
handset and their jewellery. ${ }^{21}$ This is a general complaint: the mobile phone does not only make social and business contact easier, it also facilitates crime. The mobile phone can be crucial in emergencies and many see it also as a form of security to be able to reach the police or the emergency services straightaway but many Khartoum residents also see the mobile phone as encouraging theft and offering increased opportunities for criminals. ${ }^{22}$

A number of young people regard the increased possibilities of communicating with age-mates of the opposite sex as one of the most important features of the mobile phone. 'In the past it was very difficult to communicate with the opposite sex on fixed telephones, especially in the evenings given the social norms. But the arrival of the mobile phone broke down all these borders. ${ }^{23}$ However, many people fear that this is leading to an increase in indecency and immorality. They refer to the exchange of pornographic pictures via mobile phones and to young people speaking at length to one another behind their parents' backs: 'On the negative side the mobile phone makes it more difficult for the family to follow their sons and daughters. You may find a girl talking to a boy [on the phone] in her room for the whole night.'24

Young men are sometimes pestered by women who ask them to send credit, ${ }^{25}$ while women complain of strangers calling them. Fatima, who gives her number to many women who may want to call her to make an appointment for a henna painting appointment, is sometimes harassed by male callers who she does not know.

Q: You give out your number to your customers. Have you faced any problems as a result?

A: I am annoyed by some men who call to harass me. Actually they don't even know my name and call me to speak foul language, they shock me!

Q: Could you tell me how that happened to you?

A: Once someone called me here...

Q: After you had got married?

A: Yes. He said 'Hello' to greet me. I asked him: 'Who are you?' He told me that he wanted to speak to the owner of the mobile phone. I asked him: 'Did you call this number [mentions her number]?' He said: 'Yes.' I said: 'So in that case you should actually know whose mobile phone this is.' He said: 'No, I don't know. I don't know her.' I said: 'Well, if you don't know her, then why are you calling? What do you want?' He said: 'I want a ... [refrains from mentioning the word].' So I insulted him and scolded him, insulting him and his mother and his sister; he drove me mad!

Another time somebody called me and told me that he had found my number in his mobile phone. Well, he annoyed me very much and I turned the phone off in his ear. I explained to my husband that I did not know that person. My husband was present when that person

21 Interview with a male shop worker in Khartoum city centre, 21/07/07.

22 Interview as in note 21.

23 Interview with a male student and credit transferer, Omdurman, 17/08/07.

24 Interview with a male trader at his shop in Khartoum North, 9/08/07; interview (quote) with a male credit seller on a street in Khartoum North, 10/08/07; interview with a male mobile phone shop owner in Khartoum's Arabian Market, 10/08/07.

25 Interview as in note 24. 
called me. ... My husband ordered me to end the call and not to talk to strangers anymore! 26

\section{Mobile phone culture}

\section{Modernity and social status}

The mobile phone is not only influencing patterns of social and economic interaction but is also changing notions of time, privacy and prestige. The mobile phone is becoming a part of the environment, the language and the body and, in this sense, we can talk about a 'mobile phone culture'.

The mobile phone has changed patterns of social interaction in that people may start a telephone conversation in the middle of a meeting or face-to-face conversations. Hierarchical social contact has thus come into being, whereby mobile-phone conversations take precedence over face-to-face contact. As these phone conversations may be between lovers, spouses or relatives, the boundaries of public and private space are being redesigned in the process. Conversely, people complain of being called for business purposes at most inconvenient hours, when they are relaxing or enjoying leisure activities. ${ }^{27}$

The mobile phone is seen as constituting a breach with the past: letter writing is on the decline and, as indicated above, people fear that face-to-face contact is also decreasing. The mobile phone is associated with modern life, with new dimensions of speed and immediacy. 'I depend on SMS to organize my day,' one man said. ${ }^{28}$ The mobile phone is perceived as something new and revolutionary: 'This is the age of speed and globalization. ${ }^{29}$

In its early phase, all Mobitel services were post-paid lines and customers would receive their bill afterwards. Only people with a certain income had access to this system and mobile phones were thus only available to Khartoum's well-to-do. Prepaid accounts were introduced in 1999 but customers still had to pay to receive calls. When this barrier was removed, competition started between companies to offer the best rates for their customers and the network expanded to areas outside Khartoum. Mobile telephony became more widespread and attracted customers from the middle classes and the poorer strata of society.

These two phases in the history of mobile telephony in Khartoum clearly had a bearing on the patterns of prestige related to the industry. As initially only a few people could afford a mobile phone, it was considered a sign of great wealth to possess one. 'Mobile phones invaded Khartoum recently, particularly thanks to businessmen, and rapidly became significant items of status presentation’ (Nageeb 2004:

26 Interview with a female henna painter at her house in Khartoum North, 23/09/07.

27 Interview with a male shop owner in Khartoum city centre, 21/07/07.

28 Interview with a male college graduate working at the International Center for Peace Culture in Khartoum, 7/08/07.

29 Interview as above; interview with a male credit seller on a street in Khartoum North, 10/08/07. 
26, note 3). During the first five years of mobile telephony in Sudan, having a mobile phone was regarded as an indication of prestige and riches.

With the mobile phone's increased popularity, the upper classes have felt less need to show off their cell phones and they have just become an integral part of their lives, their culture, and even their body. They always carry their phone switched on and, with money not a consideration, they use the models that give them access to all the amenities they might ever need. However, while the mobile phone has become so self-evident for them, it has become less of a mark of prestige than it used to be.

The function of status marker related to the mobile phone has shifted to middleclass residents and even to those on low incomes. They save up to buy the latest model, decorate it with lights and other accessories, equip it with fancy ring tones and wear their phone conspicuously on their belt. ${ }^{30} \mathrm{~A}$ statement from a young man who received his mobile phone as a present from a friend back in 2001 is indicative of its changing prestige: Maybe in the past it was somewhat strange to exchange a mobile phone as a gift amongst
people. It gave rise to many reactions that shows how unusual it was because of the rarity and
costs of a mobile phone. So giving it as a present was the highest limit and only for closest
relatives. But recently this has changed. You may remember that time when people told tales of
people who presented their fiancées with a mobile phone. It was regarded as a source of pride
and indicated that they were rich. But nowadays I think buying a mobile phone as a present may
be less expensive than other items that can be used as a gift. Taken from a financial perspective,
a great number of relatives and contacts may be given a mobile phone. As for me, I gave one as
a present to my fiancée and there is another one I gave away as a present. This is a normal thing
to do.31

In its brief history, the mobile phone has had consequences for the way in which social differentiation is conceptualized. Some people in Khartoum regard it as an 'equalizing' force: 'It is lessening the gap between the rich and the poor.' 32 Yet although some hold that the mobile phone has changed from being a luxury to a necessity, ${ }^{33}$ many mobile phone users still try to buy a 'good' model or attempt to turn their phone into an exclusive and special item through ring tones or accessories. Although many people from poor backgrounds cannot afford a mobile phone at all, attempts at 'distinction' through models and features counter the mobile phone's 'equalizing' tendencies.

30 Interview with a male Sudani engineer at his house in Buri, Khartoum, 20/07/07; interview with a male shop owner, Khartoum city centre, 21/07/07; interview with a male credit seller on a street in Khartoum North, 10/08/07; interview with a male student and credit transferer, Omdurman, 17/08/07.

31 Interview with a male end-user and journalist at his siter's house in Khartoum, 28/08/07.

32 Interview with a male worker at a credit transfer shop, Khartoum North, 9/08/07; interview with a male credit seller on a street in Khartoum North, 10/08/07.

33 Interview as above. 


\section{Language, numbers and popular culture}

In the context of new communication technologies, different linguistic patterns are developing. During colonial times for example, Italian, Maltese, Greek, Syrian, Turkish, Egyptian, British and Sudanese workers were all involved in the railway sector in the sprawling town of Atbara. The railway jargon used in Atbara reflected the cosmopolitan nature of these early Atbara railway workers: wardiya was used to indicate a guard or a change of duty (from the Italian guardia), wabur was used for any steamer, motor vessel or locomotive (from the French vapeur) and many English words also entered the Atbara language (Hill 1965; Sikainga 2004).

The introduction of mobile telephony likewise has been accompanied by a new vocabulary and forms of literacy. People are learning the alphabet to be able to do SMS text messaging, whereas those already using SMS may use the codes and abbreviations applied in their network. Such coded linguistic forms are particularly important for youth cultures. ${ }^{34}$

New concepts related to mobile telephony are widely used, many being borrowed from English: the word 'mobile' itself is a case in point. The various models have received nicknames. Thus the name Nokia 3310 was turned into a pun: talatain ashara (3310) shifted to hasharteen hashara (2 insects, 1 insect). The first Nokia model that could have its cover changed was called Hirboya (chameleon) but as it is now considered old-fashioned, big and heavy, its name has changed to Toba (brick). Ring tones can be associated with the insects they sound like (e.g. grasshoppers).

Most models are given a local name in addition to their official name. One Samsung model was called after the popular Syrian singer Asalah (Nasri), while another was given the name of a song (A'ashiqa) by the Lebanese female pop star Najwa Karam. As is often the case in popular culture, politics has joined the new linguistic patterns; one model is called janjaweed, another Rebecca (the name of John Garang's widow) and yet another Salva Kiir (now President of the GOSS).

Mobile telephone numbers came onto the market in a fixed order. As people associated these numbers with the specific groups that were most likely to buy a mobile phone at that time, the numbers are in line with that group. Thus numbers starting with 129 are known as Sit el shay (tea sellers), while all those that came next are identified as El talaba (students).

In the first few years of mobile phones, the numbers all started with the digits 121, 122 and 123. These numbers are now highly sought after as they are linked to the wealth and prestige of the initial phone buyers. Huge sums of money can be

34 On literacy: interview with a male Mobitel regulator and government affairs consultant at Mobitel headquarters, Mograin, Khartoum, 25/07/07. On youth culture: this is not restricted to Khartoum. The relationship between youth cultures and the new literacy of the Internet and mobile phones has been discussed elsewhere. See, for example, Wang (2005: 185-201). 
asked for numbers starting with these digits. A man who trades in handsets and SIM cards was asked whether he was interested in such numbers:

Q: Are you one of those who like special numbers and special models of mobile phone?

A: Yes, I am forced to care about this. I care about special numbers and expensive models because the number of the mobile phone has become a tool for evaluating a person. So I have found myself forced to deal with this, and I have become one of those looking for special numbers even though I have thus had to change my number many times [as a consequence]. ${ }^{35}$

Some people go out of their way to buy such a number. One of the researchers involved in the project observed how girls started laughing at a young man who had no money to call but still used an early, and hence expensive, number (Bilal 2007).

In the meantime, the mobile phone has also entered others parts of Sudanese popular culture. It has become a theme in popular songs and the phone companies sponsor television programmes. Advertisements are placed on YouTube and recently the logos used by the mobile phone companies have started to be used as henna tattoos.

\section{Landscape and reach}

For those who do not have a mobile phone, the mobile phone can seem to be omnipresent and very conspicuous. There are so many phone shops that people are confronted with the presence of the mobile phone wherever they go and there are the sometimes aggressive advertising campaigns that have come to dominate the city landscape. Entire streets are now filled with huge billboards, buildings are painted in the colours of company logos and companies take out whole-page advertisements in newspapers.

In these campaigns, the companies are trying to appeal to Sudanese sensitivities and play on issues of social bonding, relations with relatives and gender sensitivities. For example, one ad presents a mother who is told that she need not worry when her daughter leaves home to get married because with a mobile phone she will not go 'missing' as she would have in the past. The campaigns do not always fit the Sudanese context perfectly. For example, some people associate the MTN yellow (in their advertisements, MTN uses the concept 'yello') with the madness of the pink palace, called 'yellow palace' in Arabic and now a mental institution. And the word zain (Arabic for goodness or beauty) is apparently not used in colloquial language in Sudan. ${ }^{36}$

The mobile phone companies are heavily involved in social work and development projects. This is not only an international trend among multinational companies but is also related to business traditions in the Islamic world. However, quite

\footnotetext{
35 Interview with a male college graduate working at the International Center for Peace Culture in Khartoum, 7/08/07; interview with a male student and credit transferer, Omdurman, 17/08/07.

36 Informal conversation with a university teacher.
} 
a lot of people are suspicious of the motives for these activities. 'Sometimes I feel that the social projects in which these companies are involved serve no other purpose than self-promotion,' one informant stated. ${ }^{37}$ The same informants also complained that people are lured into becoming subscribers but get very little in return:

I think competition has led to good results both for the companies and the users. Yet I believe the communication companies should shift from the quantity concept to one of quality because they have already cheated a large number of customers. They focus on how to attract an everlarger number of customers but don't care about improving their services.

Some campaigns are considered misleading as the conditions are only stipulated in small letters, while the advertisement itself may be gigantic. ${ }^{38}$ Customers discuss the (dis)advantages of the promotions offered in the ad campaigns at great length and attempt to benefit as much as they can from the offers presented by the different companies. Complaints that ads do not match end-users' expectations are widespread and intensive debates may follow about the 'cheating' by this or that company.

The conspicuous presence of the mobile phone and companies' ad campaigns have transformed Khartoum's urban landscape. The mobile phone has entered daily conversation as a fully-fledged subject. In this sense, it is also very present for those who do not even possess one. The phone's impact goes far beyond its level of usage alone and has both a material and an immaterial presence in many spheres of life.

\section{In conclusion}

\section{The mobile phone in Khartoum: Changes and continuities}

The mobile phone has indeed become part and parcel of people's lives, not only in the urban landscape, in people's daily activities and in keeping in touch with family, relatives and business partners, but also in terms of identity construction and the moral debate. Over the ten years that the mobile phone has been around in Khartoum, there has been a shift from it being a status symbol for the well-to-do to it being used by the middle-classes and even poorer people. Aspects of mobile phone culture show not only in the new discourses on numbers but also in the names given to mobile phones and the ways in which people discuss 'modernity' in relation to the mobile phone. It is important to realize that in the other case studies carried out in Sudan (in Juba and Karima), the mobile phone is little used as a gadget for selfidentification. The same holds for the new linguistic categories and forms of popular culture. The Khartoum case revealed many examples of puns, nicknames and sayings related to the mobile phone. This may be explained by the phone's relatively long history in Khartoum, although another explanation could be the city's urban

37 Interview with a male end-user and journalist at his sister's house in Khartoum, 28/08/07.

38 Interview as above; informal conversation with a university graduate; interview with Deputy Director General, NTC, Khartoum, 1/08/07. 
culture where people have a different attitude to life. All over Sudan, the mobile phone is associated with youth (although in practice many elderly people also use it) but in Khartoum there is concern about the changing practices of courtship, women's mobility and social interaction.

The Khartoum case study also shows that the mobile phone's presence has led to the development of a totally new economic sector. It provides many people with an income through direct involvement in the business, or the mobile phone is used to develop economic activities, also by the poorer strata in society. This economy has introduced new linkages, for example, strong links with the commercial centre of Dubai, and between Khartoum as a distribution point and other parts of Sudan. Older long-distance economic ties are being reinforced; such as relations with Egypt and Saudi Arabia.

In addition, the mobile phone is regarded as an important device for existing businesses to reach new markets and set up different ways of organizing trade. These economic possibilities only form part of the story of the positive factors associated with the mobile phone. Social contact and personal exchange feature highly in people's evaluations of the mobile phone. As a result of the current wars and also due to economic reasons, the Sudanese context has seen a great deal of internal movement and now has a diaspora in many parts of the world. The mobile phone is seen as offering new chances to restore and/or maintain social networks with relatives and friends. As end-users, Sudanese people try to use their mobile phones in the most economic manner, trying to keep, and also enlarge, their social networks as cheaply as possible. The mobile phone has entered the system of gift exchange/remittances that is important in these networks too.

Social networks do not only include close kin. Youngsters, especially students, keep in touch with age-mates by phone, women are using the mobile phone to create new patterns of exchange with other women, and it has also come to play a crucial role in courtship and love affairs. For people whose possibilities for social exchange had previously been limited, the mobile phone constitutes a new form of freedom, offering a sense of privacy, combined with more leverage over the conditions of social interaction. This is not to say that the mobile phone has contributed to more equality in Sudanese society. On the contrary, the mobile phone reinforces, and may even have enlarged, existing social hierarchies as it functions in a complex set of meanings about modernity, trends and display. This is also reflected in popular culture; with the meanings attributed to the oldest mobile phone numbers being a case in point.

In this sense, the mobile phone is not a 'revolutionary' factor in Sudanese society: it largely confirms existing inequalities, both in terms of social status at large and within the family. However it is significant that people regard the mobile phone as 'revolutionary' and an icon of 'modernity'. The notion of modernity is prominent in 
the positive as well as in the negative evaluations of the mobile phone. Many of what are seen as the phone's advantages are at the same time evaluated as potential risks. An intense debate is being waging about sexual immorality in Islamic culture, increased opportunities for theft and organized crime, addiction to the mobile phone in a context of poverty, secretive behaviour disrupting the relationship between parents and children or husbands and wives, and people 'acting crazy' in contrast to the value placed on 'respectable behaviour'. In addition to these concerns, people are also discussing the scrupulousness of the phone companies, their unbridled campaigning that is transforming the urban landscape and the lack of control over prices and services for customers. The debates on the mobile phone in Khartoum thus include fears and concerns about morality and modernity as well as a positive evaluation of the newly gained freedoms, increased possibilities for economic enterprise, and new ways of creating and maintaining links within social networks.

\section{New media and appropriation}

The debate and usage that surround the mobile phone in Khartoum clearly flout a simple dichotomous acceptance/resistance model. In much of the literature on technology in Africa this opposition underlies the interpretation. This is not to say that a consensus exists on the effects of newly introduced communication technologies: views range from interpreting new ICTs as Western hegemony and capitalist exploitation ruinous to African 'traditions' to automatically lauding new technologies as beneficial for the development and progress of the African continent. What binds these two opposite views is that little attention is paid to local evaluations of the mobile phone, or to local interpretations of 'exploitation' and 'development' for that matter. In the final analysis, both views boil down to technological determinism. The introduction of new technologies is interpreted exclusively in terms of 'impact', 'effects' and 'consequences' on the societies concerned, be they positive or negative. The concept of appropriation points to a multi-directional approach: transformations do not only take place in the societies into which the new technologies are launched, the technologies are also transformed under the influence of local creative usages and the process of becoming embedded in a historical, cultural context. The meanings attributed to the mobile phone do not adhere to schemes of 'exploitation' or 'development' and render superfluous the discussion on new technologies being external to Africa. The functioning of the mobile phone in courtship, gift-exchange practices, popular culture and phone business in the Khartoum context has rendered it a new tool, one entirely unforeseen by its designers.

A thesis that presupposes Western tools and technology as a colonizing force misses the point of appropriation and reduces the contradictory meanings of new media to technology to a simple hegemonizing force. In an article on vampire fire- 
men stories in the East African colonial context, White also argued against an interpretation of externally introduced technologies as a purely imperial device designed to serve Western interests:

Tools and technology have recently been studied as one of the ways Europeans dominated the colonized world; they were supposed to overpower Africans or to mystify them. But the contradictory meanings of tools in these stories is too complex, and too layered, to be explained in any single way. The tools in these stories have already been assimilated; to some extent they were already familiar objects, whatever their origin. What made them fearsome was how and why they were used. (White 1993: 38-41)

The debates surrounding mobile phones in Khartoum show similar concerns. The interviews reveal how mobile telephones are made to fit into local history, how they are creatively used and what strategies have been developed to get the maximum benefit possible from this new device. At the same time, people are expressing anxiety about the ways in which this new technology is being put to use. These worries do not reflect baffled Africans confronted with externally imposed modernity that they are unable to handle nor do the positive evaluations offer proof of the development potential of new communication technologies in Africa. It might be more fruitful to view the mobile phone in Africa in terms of a process of familiarization than as a hegemonizing or developing force per se. New media have always posed new risks and offered new possibilities. This is as true in Africa as it is elsewhere. As Gitelman \& Pingree (2003: xii) put it in the introduction to New Media, 1740-1915: 'There is a moment, before the material means and the conceptual modes of new media have become fixed, when such media are not yet accepted as natural, when their own meanings are in flux'. At such moments, when the meanings and usages of emergent media are still unfixed, the interplay between technological innovation as a factor of change in society and users as agents in shaping technology is sharply apparent (Kline \& Pinch 1996: 763-95). The case of the mobile phone in Khartoum amply demonstrates the complex interplay between tools and people.

\section{Future alleys for research}

Some of the findings on mobile phone usage in Khartoum are not dissimilar to those described in other African contexts. In the Nigerian as well as in the Burkina Faso context, new dimensions in economic networks and a historical pattern from elite status symbol to more common usage can also be perceived (Smith 2006: 496523; Hahn \& Kabora 2008: 87-109). All the same, the particularities of moral debate and the in-depth nuances of the perceived (dis)advantages of the mobile phone as described above relate to the specific context of Khartoum. The civil wars, longstanding migration patterns, the debate about Islam and respectful behaviour and an urban culture are all important factors in people's understanding of mobile phone usage in Khartoum. 
In future research on mobile telephony in Khartoum these concerns and debates need specification, especially in terms of gender, generation and identity. This requires an in-depth study of the relationship between the mobile phone and older communication technologies in Sudanese history. Such historical linking would involve the relationship between older and more recent patterns of mobility as well as past and present policies and politics with regards to the new media. The latter aspect may lead to greater insight into the political economy of mobile phone technology. Much more research is still necessary into the political tensions, national policies and the relationship between the mobile phone companies and political circles in Sudan. A final issue that warrants more attention is the issue of development: how is 'development' defined and how do people view its relationship with the new communication technologies such as the mobile phone?

This contribution has proposed several alleys for future research into the study of communication technologies in Sudan. It is based not so much on theoretical considerations as on conversations held with people living in Khartoum who voiced their understandings and evaluations of the mobile phone. This descriptive framework enabled us to study local processes of appropriation and to move beyond a theoretical debate on new communication technologies as a fixed force either in 'development' or as 'hegemony'.

\section{References}

AHMAD, A.S. (2001), 'City of steel and fire': A social history of Atbara, Sudan's Railway Town, 1906-1984, Oxford: James Currey.

Bilal, H. (2007), 'The study of the social effects of the mobile phone in Northern Sudan: The cases of Khartoum and Karima', unpublished report.

DE BRUijn, M. \& I. BRINKMAN WITH H. BILAL \& P. TABAN WANI (2008), The Nile connection: Effects and meaning of the mobile phone in a (post)war economy in Karima, Khartoum and Juba, Sudan. Leiden: African Studies Centre, unpublished report.

Gitelman, L.B. \& G.B. Pingree, eds (2003), New media, 1740-1915, Cambridge: MIT Press.

GogGin, G. (2006), Cell phone culture, mobile technology in everyday life, London: Routledge.

HAHN, H.P. \& L. KABORA (2008), 'The domestication of the mobile phone: Oral society and new ICT in Burkina Faso', Journal of Modern African Studies 46(1): 87-109.

HiLl, R. (1965), Sudan transport: A bistory of railway, marine and river Services in the Republic of the Sudan, London.

Holt, P.M. \& M.W. DALY (2000), A history of the Sudan. From the coming of Islam to the Present Day, Harlow: Longman.

HORST, H.A. \& D.L Miller (2006), The cell phone. An anthropology of communication, Oxford: Berg.

HAMDAN, G. (1960), 'The growth and functional structure of Khartoum', Geographical Review 50(1): 24.

HAMDAN, G. (1960), 'The growth and functional structure of Khartoum', World Gazetteer website: http:/ $/$ www.world-gazetteer.com/wg.php? $\mathrm{x}=\& \operatorname{lng}=$ de\&dat $=32 \& g e o=-$ $188 \&$ srt $=$ pnan\&col $=$ aohdq\&men $=$ gcis $\& \operatorname{lng}=$ en $($ accessed January 2008)

KATZ, J.E. (2006), Magic in the air: Mobile communication and the transformation of social life, New Brunswick \& London: Transaction Publishers.

KLINE, R. \& T. PINCH (1996), 'Users as agents of technological change: The social construction of the automobile in the rural United States', Technology and Culture 37(4): 763-95. 
NAGEEB, S.A. (2004), New spaces and old frontiers. Women, social space, and Islamization in Sudan, Lanham: Lexington Books.

SMITH, D.J. (2006), 'Cell phones, social inequality and contemporary culture in Nigeria', Canadian Journal of African Studies 40(3): 496-523.

SPAULDING, J. (1993), 'The birth of an African private Epistolography, Echo Island 1862-1901', Journal of African History 34(1): 115-141.

WANG, J. (2005), 'Youth culture, music, and cell phone branding in China', Global Media and Communication 1(2): 185-201.

WhiTE, L. (1993), 'Cars out of place. Vampires, technology and labor in East and Central Africa', Representations 43: 38-41. 